\begin{tabular}{c}
\hline Review of \\
ECONOMICS \\
and \\
INSTITUTIONS
\end{tabular}

\title{
The Impact of Cash-Flow and the Main Components of the Capital Structure on Innovative Performances of European Firms
}

Bernardina Algieri
University of Calabria

\author{
Antonio Aquino \\ University of Calabria \\ Marianna Succurro \\ University of Calabria \\ $\mathcal{E}$ \\ Rheinische Friedrich \\ Wilhelms-Universität Bonn
}

\begin{abstract}
This study aims at investigating the impact of cash-flow, the main components of the capital structure, and R\&D on innovative performances of firms, for seven EU countries. The analysis is carried out on data taken from the EU-Efige Survey, enriched with accounting data retrieved from the Amadeus Database (Bureau Van Dijk). We consider three measures of innovative performance: product innovations, process innovations and patents. The capital structure of the firms is evaluated through the short-term debt ratio, the long-term debt ratio and the equity to total assets ratio. We also include as explanatory variables in the econometric analysis R\&D and a set of other control variables commonly employed in the empirical literature as determinants of firms' innovative performance. The results reveal that internal financial resources (cashflows) and R\&D have the greatest importance for innovative performances; the availability of long-term bank loans, a significant export propensity and a greater firm size facilitate and stimulate firms to introduce new products and production processes. Some policy implications conclude the study.
\end{abstract}

JEL classification: D22; L60; C20; O3

Keywords: Innovation; Patent; R\&D; Capital structure; Probit model

\footnotetext{
Address: University of Calabria, Department of Economics, Statistics and Finance, Ponte Pietro Bucci, Cubo 1/C, 87036 Arcavacata di Rende, Italy, Tel.: 00390984492445.

Mail: marianna.succurro@unical.it
}

\section{Recommended Citation}

Algieri, B., Aquino, A., Succurro, M., (2020). The Impact of Cash-flow and the Main Components of the Capital Structure on the Innovative Performances of European Firms. Review of Economics and Institutions, 11(1/2), Article 2. doi: 10.5202/rei.v11i1.324

Retrieved from http://www.rei.unipg.it/rei/article/view/324

2020 University of Perugia Electronic Press. 


\section{Introduction}

Capital structure and its effects on firm performance is a fundamental issue in finance and several theories have tried to explain this linkage. The capital structure of a firm regards the relative weight of its different funding sources, and in particular the combination of equity and debt a company holds. The funding sources can be internal (i.e. cash-flow) and external. The supply of external capital, via debt and equity financing, is uncertain and can be limited. Therefore, the access to internal capital can be a source of competitive advantage (Parpaleix et al. 2019; Wang and Thornhill, 2010; Barney, 1991).

Debt and equity have different implications for the governance of a company (Williamson, 1988). Debtholders can take control over the firm's assets only if it defaults or violates specific debt contracts. Conversely, large shareholders can directly intervene in the management policy. Debt financing is also less expensive than equity financing mainly due to agency costs and tax effects (Myers and Majluf, 1984). Debt financing tends, likewise, to lessen overinvestment, which helps managers to gain compensation and power, but generates no value for shareholders. Holding large debts, however, may create financial distress and increase the risk of default (Wruck, 1990; Agrawal and Maheshwari, 2019). Therefore, the amount of debt that a firm raises reflects its risk-return preferences and its management choices (Wang and Thornhill, 2010). One of the most important strategic decisions for a firm is to invest in innovation. Innovation is vital for the success of a company, for promoting international competitiveness and economic growth of firms and countries (e.g. Algieri et al. 2018; Bianchini, et al. 2018; Guariglia and Liu, 2014). Firms innovate by launching new products and introducing new production processes. The present study aims at examining which funding sources are more important for innovative performance. This means to examine the role played by internal finance (cash-flow) and external finance (debt and equity) in explaining a firm's probability to innovate. To this purpose, we here employ three measures of innovative performance: product innovations, process innovations and patents. New products and processes are the final outputs of the innovation process. Patents are the results of inventive activity (Schmookler, 1954), and thus they can be seen as an intermediate output (Griliches, 1995). However, we follow Pavitt's (1985) line of reasoning according to which: "given that patents are applied for over the whole cycle of development and commercialization of an innovation, it will be assumed that patent statistics reflect innovative - and not just inventive - activities".

We contribute to the existing literature in several ways. First, we examine the impact of cash-flow, the main components of the capital structure, and R\&D on innovative performance, a topic that has been rather overlooked in the literature. Generally, the capital structure has been associated to firms' economic performance, while few studies have been explicitly devoted to the analysis of firms' innovative performance 
(Bartoloni, 2013). The focus on capital structure is different from the analysis of the linkages between innovation and financial constraints or bank-firm relationships which have been largely explored (e.g. Aiello et al. 2020; Butzbach et al. 2020; Hall et al. 2016; Cosci et al. 2015; Savignac 2009; Mohnen et al. 2008; Herrera and Minetti, 2007; Mohnen and Roller 2005; Canepa and Stoleman 2005; Hubbard 1998; Fazzari et al. 1988). Second, while many studies have focused on single countries, we evaluate the different role played by the structure of funding sources in fostering innovations for a group of seven European economies (Austria, France, Germany, Hungary, Italy, Spain and the UK). Third, we offer a comparative analysis for three different measures of innovative performance: product innovations, process innovations and patenting activity, while most of previous studies have focused on a single measure innovative performance.

The rest of the paper is organized as follows. Section 1 presents a literature review. Section 2 describes the empirical design and method. Section 3 and 4 report and discuss the econometric results. The final section offers some conclusions and suggestions.

\section{Literature Review}

The analysis of the relationship between financial sources and firm's performance has a long history. Firms could use internal sources, such as cash-flow and retained earnings, as well as external sources, such as loans, bonds, equities and hybrid financial instruments (Stulz, 1990; Gitman and Zutter, 2012). The mix of equities and debts a firm adopts for financing its operations and assets represents the firm's capital structure.

Several empirical studies on the linkage between innovative investments and financial constraints have been carried out over time ${ }^{1}$. Among the others, Hall (1992) documented that financing constraints can hamper profitable $R \& D$ investment opportunities ${ }^{2}$ when firms fall short of internal resources. Hottenrott and Peters (2012) argued that 'more money' lead to more innovations, while Musso and Schiavo (2008) and Almeida et al. (2013) claimed that financial constraints can favour the selection of more efficient innovative projects, so that 'less money' could trigger greater innovative performance. In a recent work, Aiello et al. (2020) have assessed the impact of different types of financial sources on the innovation activities of small and medium enterprises in the EU and

1 See David et al. (2000) and Hall et al. (2016) for a detailed survey of the existing research.

2 In empirical research, innovative firms are often identified as carrying on some research and development (Magri, 2009). This is because investments or expenditures in $R \& D$ are intended to produce innovations, but given that R\&D investments can lead only to "potentially innovative" firms - i.e. R\&D is neither a sufficient nor necessary condition for either innovation activity or innovation to occur- the variable is an imperfect measure for innovation. 
found that innovation is positively influenced by different fonts of financing, mainly by internal funds and grants.

The literature on the linkage financial sources and innovative investments versus physical investments is less copious. Investments in innovation differ from physical investments for their intangibility and the high degree of uncertainty associated with their effects. The typical problem of asymmetric information between firms and investors becomes even more relevant in a R\&D setting: since investors have more difficulties to distinguish between good and bad projects, the "lemon premium" for the development of innovative ideas is higher than for physical investments. In addition, the reduction of asymmetric information through complete disclosure is of limited effectiveness in the case of $R \& D$ investments, given that creative ideas can be easily replicated. For these reasons, firms will face even higher costs for external than internal financial resources when they invest in $R \& D$ activities as opposed to physical investments (Mina, 2013; Hall and Lerner 2010; Cosh et al. 2009; Hall 2002).

The question whether debt or equity should be preferred by $R \& D$ intensive firms is rather more complicated. According to Carpenter and Petersen (2002) and Brown, Fazzari and Petersen (2009) using equity instead of debt for financing has several advantages for high-tech firms in the US. Aghion et al. (2004) and Wang and Thornhill (2010) find a nonlinear relationship between the debt/asset ratio and the firm's R\&D profile. Firms with both high $R \& D$ and those with zero $R \& D$ tend to use less debt finance than firms with positive, but less intensive R\&D. According to Aghion and Bolton (1992) and Aghion et al. (2004), there is an incentive for firms to allocate fuller control rights to external investors by issuing equity when the size or scope of the investment becomes sufficiently large and when assets become sufficiently intangible.

The aim of this study is to offer additional empirical evidence on the impact of cash-flow, the main components of capital structure and R\&D investments on firms' innovative performance. Differently from previous studies (e.g. Aiello et al. 2020), we use three different indicators of innovative performance and consider innovative those firms that declare they have introduced either novelties in their production processes or in their products and those firms that have carried out patenting activities. We further supplement the Efige dataset with firms' balance sheets so to ensure cross-sectional comparability.

\section{Data and Methodology of the Empirical Analysis}

\subsection{Data}

To evaluate the impact of capital structure on firms' innovative performance, we have collected data from the latest EU-Efige Survey, enriched with accounting data retrieved from the Amadeus Database (Bureau Van Dijk). The data consist of a representative sample - at the 
country level and for manufacturing industry - of almost 13,000 firms in seven European countries (Germany, France, Italy, Spain, United Kingdom, Austria and Hungary) (Table 1). Each firm has a minimum of 10 employees; therefore, the survey excludes micro-enterprises. Firms' innovative activity has been observed over the years 2007-2009, while data on capital structure and other firm characteristics have been collected at the beginning of the observation period. We consider as innovative, those firms that have carried out product or process innovations (as in Magri, 2009; Giannetti, 2012; Cosci et al., 2015), as well as those that have succeeded in patenting. As highlighted in Cosci et al. (2015), this strategy has the advantage of capturing innovations that may occur even in absence of formalized $R \& D$ projects. This is particularly true for small firms which represent the majority of our sample $(73.31 \%$ are small firms -with 10 to 49 employees; 20.28\% are medium enterprises -with 50 to 249 employees; $6.40 \%$ are large companies -with 250 or more employees).

Table 1 illustrates the distribution of manufacturing firms across countries and the relative percentage of innovative firms and those performing R\&D activities. The percentage of firms innovating with products and processes ranges from 56\% in France to $77 \%$ in Austria. The percentage of firms investing in $R \& D$ is lower than the percentage of firms introducing new processes and/or products. This feature signals that several innovative firms have not carried out any formal R\&D activity. The largest difference is observed for Spain, where about $70 \%$ of the firms declared to have introduced new processes and/or products, but less than $50 \%$ declared to have invested in R\&D. It should be noted, however, that an uncertain - sometimes long - period of time may pass between a given $R \& D$ investment and the subsequent product or process innovations.

Table 1. Innovative Firms by Country

\begin{tabular}{lccccc}
\hline & $\begin{array}{c}\text { Number of } \\
\text { Firms }\end{array}$ & $\%$ & $\begin{array}{c}\text { Firms with product } \\
\text { and process } \\
\text { innovations }\end{array}$ & $\begin{array}{c}\text { Firms with patent } \\
\text { applications }\end{array}$ & $\begin{array}{c}\text { Firms undertaking } \\
\text { R\&D investments \% }\end{array}$ \\
\hline Austria & 338 & 2.64 & 76.92 & 21.00 & 57.98 \\
France & 2,727 & 21.30 & 55.66 & 11.69 & 50.45 \\
Germany & 2,329 & 18.19 & 65.09 & 16.10 & 56.16 \\
Hungary & 311 & 2.43 & 58.19 & 4.50 & 27.00 \\
Italy & 2,769 & 21.63 & 67.96 & 14.08 & 55.20 \\
Spain & 2,448 & 19.12 & 69.44 & 11.27 & 46.65 \\
UK & 1,882 & 14.70 & 67.16 & 14.02 & 53.34 \\
tot. & 12,804 & 100 & & & \\
\hline
\end{tabular}

Source: own elaborations on Efige dataset

Finally, the percentage of firms with patent applications is relatively low in all the considered countries. This low value can be due to the very high costs of patenting or to strategic reasons, i.e. the choice of firms to protect their innovations in an informal way, such as industrial and/or commercial secrecy. 
As regards the overall composition of firms' capital structure, Efige data (Section $\mathrm{F}$ of the survey, question $\mathrm{F}^{3}$ ) show that about $45.32 \%$ of the firms use external financing, distributed among debts (loans, debt securities and other financial instruments) and equities.

With respect to the instruments of external finance through debt (Table 2), $62.62 \%$ of these firms make use of medium to long-term bank loans (and about $44.74 \%$ of them attribute a weight greater than $50 \%$ to this financing source); $56.23 \%$ of the firms utilize short-term bank debt (and for $34 \%$ of them this financial channel has a relevance greater than $50 \%$ ); $19.8 \%$ of the firms consider other financial instruments $(12.31 \%$ of them attribute a weight greater than $50 \%$ to this financial channel). A smaller importance is attributed to short-term and long-term securities, since more than $94 \%$ of the firms do not employ this financing channel.

Table 2. Firm's Capital Structure (Percentage Values)

\begin{tabular}{|c|c|c|c|c|c|c|}
\hline \multirow[t]{2}{*}{ Debt } & \multicolumn{6}{|c|}{ Relevance } \\
\hline & $0 \%$ & $1-19 \%$ & $20-49 \%$ & $>=50 \%$ & n.a* & \\
\hline short-term bank loans (up to 12 months) \% & 36.88 & 9.7 & 12.6 & 33.93 & 6.89 & 100 \\
\hline $\begin{array}{l}\text { medium to long-term bank loans ( } 12 \text { months } \\
\text { and over) \% }\end{array}$ & 23.88 & 5.98 & 11.9 & 44.74 & 13.5 & 100 \\
\hline $\begin{array}{l}\text { short-term securities (bonds and debentures) } \\
\%\end{array}$ & 94.26 & 3.14 & 1.42 & 0.18 & 1 & 100 \\
\hline $\begin{array}{l}\text { medium and long-term securities (bonds and } \\
\text { debentures) \% }\end{array}$ & 94.38 & 2.15 & 3.42 & 0.05 & - & 100 \\
\hline other financial instruments \% & 76.45 & 4.02 & 3.47 & 12.31 & 3.75 & 100 \\
\hline \multirow[t]{2}{*}{ Equity } & & Yes (\%) & & No (\%) & & \\
\hline & & 15.98 & & 84.05 & & 100 \\
\hline
\end{tabular}

Note: * n.a. indicates not available answers.

Source: own elaborations on Efige dataset.

On average, $16 \%$ of the firms ${ }^{4}$ of the sample use equities to raise funds to satisfy their financing needs. This percentage ranges from $11.8 \%$ in Spain to $30.1 \%$ in Germany.

It is worth noticing that companies that use more debt than equity to finance assets have a high leverage ratio and an aggressive capital structure. A company that pays for assets with more equity than debt has a low leverage ratio and a conservative capital structure. A high leverage ratio and/or an aggressive capital structure can also lead to higher growth

3 Question F1 of the questionnaire asks: "What is the overall distribution of your firm's debt structure in percentage terms?". Possible answers include: short-term bank debt (up to 12 months) (\%); medium to long-term bank debt (12 months and over) (\%); short-term securities (\%); medium and long-term securities (\%); other financial instruments (\%) (total 100\%).

4 Question F6 of the questionnaire asks: What kind of financial instruments have been used to satisfy your firm's financing needs?- Equity - Venture capital and private equity - Short-term bank credit - Medium or long-term bank credit - Securities - Public funds - Tax incentives - Leasing or factoring - Other financing methods. 
rates, whereas a conservative capital structure can lead to lower growth rates. The goal of management is, hence, to find the optimal capital structure $^{5}$. The choice between debt financing or equity financing depends on several factors, including the easiness to access to a given funding source, the company's cash flow (self-financing) and the relative importance of maintaining control on the company. Actually, most enterprises use a combination of debt and equity financing; indeed, $11.4 \%$ of the firms utilize equity and short-term or long-term bank debts.

\subsection{The Empirical Model}

The response variable of our analysis is dichotomous; hence, we estimate a probit model. More specifically, we assume that each firm is characterized by a latent propensity to innovate, denoted as $\mathrm{y}_{\mathrm{i}}^{*}$ and generated by the following process:

$$
y_{i}^{*}=\beta^{\prime} X_{i}+u_{i}
$$

where the set of regressors $X$ includes the firms' capital structure, as well as the other control variables described below. Assuming that a firm innovates when $y_{i}^{*}>0$, and specifying an indicator function $y_{i}$, such that:

$$
\begin{aligned}
& y_{i}=1 \text { if } y_{i}^{*}>0 \\
& y_{i}=0 \text { if } y_{i}^{*} \leq 0
\end{aligned}
$$

the probability to innovate is the probability that the latent propensity is larger than zero:

$$
\begin{gathered}
\operatorname{Pr}\left(y_{i}=1 \mid X_{i}\right)=\operatorname{Pr}\left(y_{i}^{*}>0 \mid X_{i}\right)=\operatorname{Pr}\left(\beta^{\prime} X_{i}+u_{i}>0 \mid x_{i}\right)=\operatorname{Pr}\left(u_{i}>-\beta^{\prime} X_{i} \mid x_{i}\right) \\
=F\left(\beta^{\prime} X_{i}\right)
\end{gathered}
$$

Using the cumulative distribution function of the standard normal distribution, $\Phi$, for $F\left(\beta^{\prime} X_{i}\right)$ and specifying the $X$ vector yields our estimating probit model ${ }^{6}$ :

$$
\operatorname{Pr}\left(\operatorname{INN}_{i, t}=1 \mid X\right)=\Phi\left(\beta_{0}+\delta C S_{i, t-3}+\phi C T R L_{i, t-3}\right)
$$

where $t=2009$ and the dichotomous variable INN (innovation) is coded 1 if firm $\mathrm{i}$ has innovated over the 2007-2009 period, 0 otherwise. The variable INN identifies three different measures of innovation output: product innovation, process innovation and patenting activities. By

The ideal debt to equity ratio is usually considered to be around 2:1.

6 Choosing the logistic distribution function (i.e., the logit model) would not affect our results. 
product innovation we mean the introduction of a good which is either new or significantly improved with respect to its fundamental characteristics (innovation is meant to be new to the firm, not necessarily to the market). By process innovation we refer to the adoption of a production technology which is either new or significantly improved (again, innovation is new to the firm, but the firm should not be the first to introduce this process). By patents we refer to a grant of protection for an innovation and/or invention. It is well-known that the prime purpose of patenting activity by industrial firms is to protect their innovations against imitation by competitors, that such protection is temporary, and that patents are just one means of protection along with secrecy, natural imitation lags, and firm-specific skills and know-how. On the right-hand side, the probability of innovating is defined as a function of a firm's cash-flow, the capital structure, R\&D investments7 and a set of control variables all observed at the beginning of the period and commonly employed in the empirical literature as determinants of a firm's innovative performance. It is worth noticing that previous researches have suggested that the relation between finance and innovation runs from finance to innovation (e.g. Bartoloni, 2013); however, as a first step to limit the endogeneity problem due to reverse causality, we consider the average of innovation activities over the years 2007-2009, while the set of explanatory variables refer to $2007^{8}$. Specifically, the cash-flow on total assets ratio (CF/TA) is our measure of internal finance. The capital structure of the firms is measured through different financial ratios: the short-term debt ratio (STDR) computed as short-term bank debt over total assets (Mohohlo, 2013; Gill et al., 2011); the long-term debt ratio (LTDR) calculated as long-term bank debt to total assets and the equity to total assets ratio (E/TA) (Singh and Bagga, 2019). A negative association between short-term or long-term bank debt ratios and firm profitability has been found in many previous studies (e.g. Purwohandoko, 2017; Gill et al. 2011); however, in some analyses, no statistical relationship has been found. We add the R\&D expenditure over total sales at the beginning of the period ( $R \& D /$ sales). Previous research suggests that investments in $R \& D$ increase the probability of introducing a product or process innovation, although the probability that such investments will sufficiently increase a firm's future productivity is less than one (e.g. Griffith et al., 2006). Further findings reveal that the likelihood of being an innovator is positively associated with the R\&D intensity; however, some firms do not innovate despite engaging in R\&D activities. This suggests that $R \& D$ investments are risky, and the outcome is uncertain. In addition, there can be innovative firms without formally budgeting for R\&D. Other firms' characteristics have been included as control variables, namely:

7 We consider firms' R\&D activities as a whole, without distinguishing between internal or external R\&D which, on the contrary, is the focus of other works (see Aiello et al. 2020, b).

8 Note that we deal with the endogeneity problem in paragraph 4. 
- The size of the company (SIZE), measured by the natural logarithm of total assets (Javed et al. 2014; Frank and Goyal, 2003). According to previous works (Beck et al. 2005, among others), the firm's size is significantly associated with its performance. In comparison to small firms, larger firms tend to have a greater diversification of activities, larger economies of scale and higher capacities and resources (Frank and Goyal, 2003). Hence, we expect a positive impact of firms' size on their innovative performance.

- The age of the firm (AGE), measured by the number of years since its foundation. Previous studies obtained conflicting results on the impact of age on firm innovative performance. On one side, it has been argued that by utilizing their reputation, larger market shares, customers' loyalty and distribution channels, older firms could generate more sales, be more profitable and innovative (Graham and Harvey, 2001). On the other side, Huergo and Jaumandreu (2004) pointed out that a firm becomes obsolete when it gets older, so facing difficulties to adopt the requested changes in the business environment.

- The propensity to export (EXPORTER), measured by a dummy variable that takes value 1 if the company sells its products abroad and 0 otherwise. We expect a positive relationship between export propensity -a signal of firm dynamism- and innovative performance.

- Group membership (GROUP), proxied by a dummy variable equal to 1 if the firm belongs to a group, 0 otherwise. Being a member of a group can facilitate knowledge spillovers. Moreover, as highlighted in Cosci et al. (2015), firms that are part of a group may have access to additional capital through their parent companies.

- The ratio between high skilled workers and total employees (HSW).

- The total factor productivity (TFP), as a measure of the firm's internal efficiency. TFP is calculated according to Levinsohn and Petrin's semi-parametric algorithm, as explained in Altomonte et al. (2013).

- The ownership concentration of companies $(\mathrm{OWN})$, given by the percentage of ownership held by the main shareholder. Empirical evidence on the effect of ownership concentration on firm innovation is conflicting. While some studies show a positive relationship (Costanzo and Succurro 2018; Chen et al. 2014; Hosono et al. 2004; Francis and Smith 1995), others found a negative relationship (Minetti et al. 2015; Yafeh and Yosha 2003) or no associations (Shapiro et al. 2015).

Finally, the set of control variables also include country and industry dummies?.

9 To preserve the anonymity of the surveyed firms, Efige dataset provides information on industrial sectors in the form of a randomised identifier ranking from 1 to 11 . These values do not map any particular ordering of the original data. 


\subsection{Descriptive Statistics}

Table 3 illustrates some descriptive statistics for the sub-samples of innovative (with product or process innovations) and non-innovative firms (Panel A), and for patenting and non-patenting firms (Panel B).

Table 3. Summary Statistics

\begin{tabular}{|c|c|c|c|c|c|c|c|c|c|}
\hline \multirow[b]{2}{*}{$\begin{array}{l}\text { Panel A: } \\
\text { Innovation }\end{array}$} & \multicolumn{4}{|c|}{ Innovative firms } & \multicolumn{4}{|c|}{ Non-innovative firms } & \multirow{2}{*}{$\begin{array}{l}t \text {-Test } \\
p \text {-value }\end{array}$} \\
\hline & Mean & $\begin{array}{l}\text { Std. } \\
\text { Dev. }\end{array}$ & Min & Max & Mean & $\begin{array}{l}\text { Std. } \\
\text { Dev. }\end{array}$ & Min & Max & \\
\hline CF/TA & 0.003 & 0.004 & -0.002 & 0.0208 & 0.004 & 0.005 & -0.002 & 0.021 & 0.000 \\
\hline STDR & 0.029 & 0.016 & 0.000 & 0.075 & 0.020 & 0.018 & 0.000 & 0.075 & 0.000 \\
\hline LTDR & 0.007 & 0.005 & 0 & 0.025 & 0.006 & 0.005 & 0 & 0.025 & 0.000 \\
\hline $\mathrm{E} / \mathrm{TA}$ & 0.269 & 4.297 & -378 & 1 & -0.028 & 17.910 & -1078.875 & 1 & 0.010 \\
\hline R\&D/sales & 0.733 & 0.442 & 0 & 1 & 0.364 & 0.481 & 0 & 1 & 0.000 \\
\hline SIZE & 12653 & 27516 & 428.3 & 263511 & 7711.8 & 19809 & 419.2 & 264366 & 0.000 \\
\hline AGE & 43.761 & 30.648 & 9 & 198 & 41.854 & 28.548 & 0 & 192 & 0.000 \\
\hline EXPORTER & 0.748 & 0.433 & 0 & 1 & 0.532 & 0.498 & 0 & 1 & 0.000 \\
\hline GROUP & 0.240 & 0.427 & 0 & 1 & 0.186 & 0.389 & 0 & 1 & 0.185 \\
\hline HSW & 0.626 & 0.258 & 0 & 1 & 0.646 & 0.271 & 0 & 1 & 0.100 \\
\hline TFP & -0.758 & 0.620 & -7.086 & 4.138 & -0.715 & 0.596 & -4.996 & 3.669 & 0.234 \\
\hline \multirow[t]{2}{*}{ OWN } & $6.26 e+07$ & $7.89 e+1$ & 0 & 100 & $4.65 e+07$ & $6.80 e+1$ & 0 & 100 & 0.000 \\
\hline & \multicolumn{4}{|c|}{ Patenting firms } & \multicolumn{4}{|c|}{ Non-patenting firms } & $t$-Test \\
\hline $\begin{array}{l}\text { Panel B: } \\
\text { patents }\end{array}$ & Mean & $\begin{array}{l}\text { Std. } \\
\text { Dev. }\end{array}$ & Min & $p$-value & Mean & $\begin{array}{l}\text { Std. } \\
\text { Dev. }\end{array}$ & Min & Max & $p$-value \\
\hline CF/TA & 0.002 & 0.003 & -0.002 & 0.021 & 0.004 & 0.004 & -0.002 & 0.021 & 0.000 \\
\hline STDR & 0.025 & 0.014 & 0.000 & 0.074 & 0.011 & 0.017 & 0.000 & 0.075 & 0.000 \\
\hline LTDR & 0.007 & 0.004 & 0 & 0.024 & 0.004 & 0.005 & 0 & 0.025 & 0.000 \\
\hline $\mathrm{E} / \mathrm{TA}$ & 0.288 & 1.446 & -54.01 & 1 & 0.146 & 11.966 & -1078.87 & 1 & 0.002 \\
\hline R\&D/sales & 0.895 & 0.305 & 0 & 1 & 0.559 & 0.496 & 0 & 1 & 0.001 \\
\hline SIZE & 21412 & 37610 & 456 & 243362 & 9256 & 22139 & 419.2 & 264366 & 0.000 \\
\hline AGE & 46.465 & 31.760 & 10 & 181 & 42.576 & 29.620 & 9 & 198 & 0.000 \\
\hline EXPORTER & 0.895 & 0.305 & 0 & 1 & 0.638 & 0.480 & 0 & 1 & 0.000 \\
\hline GROUP & 0.362 & 0.480 & 0 & 1 & 0.200 & 0.400 & 0 & 1 & 0.101 \\
\hline HSW & 0.614 & 0.256 & 0 & 1 & 0.636 & 0.264 & 0 & 1 & 0.102 \\
\hline TFP & -0.842 & 0.619 & -7.086 & 1.300 & -0.727 & 0.610 & -4.996 & 4.138 & 0.099 \\
\hline OWN & $8.58 e+07$ & $9.22 \mathrm{e}+1$ & 0 & 100 & $5.26 e+07$ & $7.23 e+1$ & 0 & 100 & 0.000 \\
\hline
\end{tabular}

Note: $\mathrm{CF} / \mathrm{TA}=$ cash-flow on total assets; $\mathrm{STDR}=$ short-term debt ratio; LTDR=long-term debt ratio; $\mathrm{E} / \mathrm{TA}=\mathrm{equity}$ to total assets; R\&D/sales=R\&D on sales; SIZE=size of the company; $A G E=$ age of the company; EXPORTER=propensity to export; GROUP=group membership; HSW=high skilled workers; TFP=total factor productivity; OWN=ownership concentration. The $t$-test reported on the last column is on the difference of the means between the indicated sub-samples. The size of the firm is measured by total assets (thousands euros).

The t-test on the difference of the means between the sub-samples is reported in the last column, while the correlation coefficients between the variables are reported in Table A.1 in the Appendix. At first sight innovative firms seem to be characterized by smaller internal financial resources. At the same time, they appear to be more indebted than non-innovative firms. 
Moreover, on average, innovative firms would recur to equity more frequently than non-innovative firms, even if the difference between the sub-samples is less significant when considering the equity ratio. With reference to the firms' characteristics, innovative firms tend to be larger, older and characterized by a relatively higher ownership concentration and propensity to export. The difference of the means is statistically significant for most of the explanatory variables, except for the percentage of high-skilled workers, the fact that a company belongs to a group and the total factor productivity.

\section{Empirical Results}

Table 4 shows the estimation results of the probit regression for each measure of the innovative performance: process innovations, product innovations and patenting activity.

We distinguish between a baseline model with firms' cash-flow, debts, equities, R\&D, age and size as main explanatory variables (regressions 1, 2 and 3) and an extended model with all controls (regressions 4, 5 and 6). A positive marginal effect indicates that a rise in the corresponding explanatory variable increases the probability of generating innovations.

The estimated coefficient of cash-flow over total assets has a positive sign and is significant at $1 \%$ or $5 \%$ level in almost all regressions. This result highlights the importance of internal financial resources for the firms' innovative performance. In particular, an increase in the (log of the) cash-flow ratio by one unit rises the probability of obtaining product innovation by approximately 0.03 , the probability of process innovation by about 0.11 and the probability of patenting by 0.06 for the baseline model. The results are similar for the extended model and confirm that greater liquidity fosters companies to undertake innovative activities.

Differently from previous works which focus only on product innovation (Aiello et al. 2020), we distinguish between product and process innovations and patenting by evaluating the impact of both short-term and long-term debt on innovative performance. The econometric findings show interesting results. Indeed, while Aiello et al. (2020) find that the use of bank loans does not exert any influence on firms' probability to introduce a product innovation, we find a significant impact of short-term bank loans on process innovation and a significant influence of long-term debt on all three measures of innovations. More specifically, the debt ratios enter the model with a positive sign, but while the short-term debt ratio affects only the probability of obtaining process innovations, the long-term debt ratio is strongly significant in all the estimations. The positive debt signs would signal the importance of bank credit to finance innovation, especially in the European bank-based system ${ }^{10}$. Indeed, the access to a bank credit line stimulates companies to undertake more innovative projects.

10 Note that when we run regressions separately for each country (not reported to save space, but available upon request), debt ratios enter at lower levels of significance for 
Table 4. Probit Estimations

\begin{tabular}{|c|c|c|c|c|c|c|}
\hline Variables & $\begin{array}{l}\text { Product } \\
\text { innovations }\end{array}$ & $\begin{array}{l}\text { Process } \\
\text { innovations }\end{array}$ & Patents & $\begin{array}{l}\text { Product } \\
\text { innovations }\end{array}$ & $\begin{array}{l}\text { Process } \\
\text { innovations }\end{array}$ & Patents \\
\hline & $\begin{array}{l}\text { baseline } \\
(1)\end{array}$ & $\begin{array}{l}\text { baseline } \\
(2)\end{array}$ & $\begin{array}{l}\text { baseline } \\
(3)\end{array}$ & $\begin{array}{l}\text { extended } \\
(4)\end{array}$ & $\begin{array}{l}\text { extended } \\
(5)\end{array}$ & $\begin{array}{l}\text { extended } \\
(6)\end{array}$ \\
\hline \multirow[t]{2}{*}{ In CF/TA } & $0.032 * *$ & $0.110 * * *$ & $0.061 * *$ & $0.018 * *$ & $0.073 * * *$ & $0.064 * *$ \\
\hline & 0.013 & 0.018 & 0.023 & 0.008 & 0.019 & 0.028 \\
\hline \multirow[t]{2}{*}{ In STDR } & 0.009 & $0.051^{*}$ & 0.033 & 0.032 & $0.106 * *$ & 0.040 \\
\hline & 0.033 & 0.031 & 0.039 & 0.049 & 0.049 & 0.063 \\
\hline \multirow[t]{2}{*}{ In LTDR } & $0.031 * *$ & $0.062 * * *$ & $0.051 * *$ & $0.028 *$ & $0.057^{* * *}$ & $0.061 * * *$ \\
\hline & 0.013 & 0.014 & 0.018 & 0.019 & 0.018 & 0.013 \\
\hline \multirow[t]{2}{*}{ In E/TA } & 0.015 & 0.005 & 0.045 & -0.002 & 0.006 & 0.028 \\
\hline & 0.025 & 0.024 & 0.062 & 0.033 & 0.033 & 0.056 \\
\hline \multirow[t]{2}{*}{ R\&D/sales } & $0.949 * * *$ & $0.547 * * *$ & $0.057 * * *$ & $0.951 * * *$ & $0.519 * * *$ & $0.178 * * *$ \\
\hline & 0.032 & 0.032 & 0.016 & 0.043 & 0.042 & 0.030 \\
\hline \multirow[t]{2}{*}{ In AGE } & 0.040 & -0.018 & 0.012 & 0.058 & -0.032 & -0.062 \\
\hline & 0.059 & 0.030 & 0.036 & 0.081 & 0.040 & 0.073 \\
\hline \multirow[t]{2}{*}{ In SIZE } & $0.121 * * *$ & $0.221 * * *$ & $0.315^{* * *}$ & $0.056^{*}$ & $0.260 * * *$ & $0.273 * * *$ \\
\hline & 0.040 & 0.039 & 0.049 & 0.032 & 0.060 & 0.077 \\
\hline \multirow[t]{2}{*}{ EXPORTER } & & & & $0.287 * * *$ & $0.068 *$ & $0.437 * * *$ \\
\hline & & & & 0.047 & 0.046 & 0.091 \\
\hline \multirow[t]{2}{*}{ GROUP } & & & & 0.066 & 0.030 & 0.007 \\
\hline & & & & 0.082 & 0.054 & 0.077 \\
\hline \multirow[t]{2}{*}{ HSW } & & & & 0.085 & 0.021 & $0.219 * *$ \\
\hline & & & & 0.102 & 0.075 & 0.098 \\
\hline \multirow[t]{2}{*}{ TFP } & & & & 0.191 & $0.114^{* *}$ & 0.014 \\
\hline & & & & 0.210 & 0.050 & 0.076 \\
\hline \multirow[t]{2}{*}{ In OWN } & & & & 0.023 & 0.002 & 0.025 \\
\hline & & & & 0.025 & 0.003 & 0.027 \\
\hline \multirow[t]{2}{*}{ constant } & $-1.327 * * *$ & $-1.038 * *$ & $-2.817 * * *$ & 2.623 & -0.973 & $-2.943 * * *$ \\
\hline & 0.378 & 0.441 & 0.375 & 149.349 & 1.093 & 0.731 \\
\hline \multirow{2}{*}{$\begin{array}{l}\text { country effects } \\
\text { sector effects }\end{array}$} & yes & yes & yes & yes & yes & yes \\
\hline & yes & yes & yes & yes & yes & yes \\
\hline Number of obs & 7,523 & 7,523 & 4,010 & 4,347 & 4,347 & 4,346 \\
\hline LR chi2 & 1383.24 & 633.43 & 380.56 & 870.84 & 355.67 & 548.70 \\
\hline Prob > chi2 & 0.000 & 0.000 & 0.000 & 0.000 & 0.000 & 0.000 \\
\hline Pseudo R2 & 0.1326 & 0.064 & 0.1025 & 0.1446 & 0.0592 & 0.1581 \\
\hline Log likelihood & -4522.273 & -4879.359 & -2021.393 & -2575.830 & -2825.925 & -1461.047 \\
\hline
\end{tabular}

The coefficient of the equity ratio is not statistically significant. This result, in line with Magri (2014), indicates that issuing equity would not

the United Kingdom which, differently from the other countries, is not a bank-based economy, but a market-based financial system. 
affect the probability to obtain product or process innovation or firms' patenting decisions ${ }^{11}$. The findings would indicate that external finance can be very costly for innovative firms, which is the reason why they finance, patenting and product/process innovations mainly out of their internally generated resources. This corroborates the findings by Hall (2009). The variable R\&D exerts a strong and significant impact on firms' innovative performance, and the effect is relatively more important for product and process innovations than patents, and stronger for new products than new processes. This result is in line with Baumann and Kritikos (2016). As for the other control variables, the size of the company, measured by total assets, is always significant and increases the probability of innovation. The result is in line with Schumpeter's idea according to which larger companies have a greater propensity to innovate than smaller companies due to their higher economies of scale and larger availability of tangible and intangible resources. The age of the company does not influence the probability of obtaining additional product innovations, process innovations or patenting, while the propensity of the company to export is a significant factor that pushes innovative activities and signals a relevant firm dynamism. Certainly, more competition on international markets fosters innovations, while less competition reduces the incentives for firms face to innovate. The econometric results suggest that being a member of a group would not influence firms' innovative performance. Analogously, ownership concentration does not seem to influence the probability of additional innovations. TFP would exert a positive and significant impact only on process innovations, while it is not significant in other regressions. With reference to the potential impact of high skilled workers, an increase in the share of qualified employees does not seem to exert any influence on the probability of undertaking product or process innovations, but it tends to increase the probability of generating more patents. On the whole, the empirical results show that there is a positive impact on innovative performance from the availability of internal financial resources, the long-term debt ratio, $R \& D$ investments, the size of the firm and its export propensity. The significance of the cash-flow variable indicates that a large availability of internal financial resources could significantly foster innovative activities, while a lack of internal finance could hinder innovation (Hyytinen and Toivanen, 2005). Hereafter, we control for alternative financial instruments used by the firm (that is financial channels different from cash-flow, debt or equity).

In Table 5, we control for external financial instruments different from short-term bank debt and medium to long-term bank debt.

11 Actually, when we run regressions separately for each country, the econometric results suggest that the variable equity/total assets would significantly explain product/process innovations and patenting activity in the United Kingdom. The UK stock market, indeed, is one of the largest stock markets and it is expected to positively contribute to firms' innovative activity. 
Table 5. Probit Estimations - Other Financial Instruments

\begin{tabular}{|c|c|c|c|}
\hline Variables & $\begin{array}{l}\text { Product } \\
\text { innovations }\end{array}$ & $\begin{array}{l}\text { Process } \\
\text { innovations }\end{array}$ & Patents \\
\hline & (1) & (2) & (3) \\
\hline \multirow[t]{2}{*}{$\ln \mathrm{CF} / \mathrm{TA}$} & $0.021 *$ & $0.078 * * *$ & $0.078 *$ \\
\hline & 0.011 & 0.026 & 0.041 \\
\hline \multirow[t]{2}{*}{ In STDR } & 0.003 & $0.081^{*}$ & 0.059 \\
\hline & 0.045 & 0.049 & 0.077 \\
\hline \multirow[t]{2}{*}{ In LTDR } & $0.023^{*}$ & $0.050 * * *$ & $0.078 * * *$ \\
\hline & 0.019 & 0.013 & 0.031 \\
\hline \multirow[t]{2}{*}{ In $\mathrm{E} / \mathrm{TA}$} & -0.030 & 0.011 & 0.062 \\
\hline & 0.043 & 0.018 & 0.056 \\
\hline \multirow[t]{2}{*}{ dSTS } & -0.039 & -0.190 & 0.094 \\
\hline & 0.124 & 0.121 & 0.173 \\
\hline \multirow[t]{2}{*}{ dMLTS } & -0.105 & $-0.234^{*}$ & -0.129 \\
\hline & 0.123 & 0.120 & 0.172 \\
\hline \multirow[t]{2}{*}{ dOFI } & 0.078 & $0.172 * * *$ & -0.080 \\
\hline & 0.111 & 0.061 & 0.091 \\
\hline \multirow[t]{2}{*}{ R\&D/sales } & $0.949 * * *$ & $0.510 * * *$ & $0.012^{* * *}$ \\
\hline & 0.043 & 0.042 & 0.003 \\
\hline \multirow[t]{2}{*}{ In AGE } & 0.059 & -0.033 & -0.058 \\
\hline & 0.091 & 0.040 & 0.060 \\
\hline \multirow[t]{2}{*}{ In SIZE } & $0.036 *$ & $0.225^{* * *}$ & $0.341 * * *$ \\
\hline & 0.020 & 0.061 & 0.096 \\
\hline \multirow[t]{2}{*}{ EXPORTER } & $0.284 * * *$ & $0.063^{*}$ & $0.554 * * *$ \\
\hline & 0.048 & 0.046 & 0.091 \\
\hline \multirow[t]{2}{*}{ GROUP } & 0.074 & 0.036 & -0.015 \\
\hline & 0.083 & 0.055 & 0.077 \\
\hline \multirow[t]{2}{*}{ HSW } & 0.087 & 0.033 & $0.213^{* *}$ \\
\hline & 0.108 & 0.075 & 0.110 \\
\hline \multirow[t]{2}{*}{ TFP } & -0.186 & $0.114^{* *}$ & 0.025 \\
\hline & 0.250 & 0.050 & 0.076 \\
\hline \multirow[t]{2}{*}{ In OWN } & 0.025 & 0.005 & 0.028 \\
\hline & 0.027 & 0.025 & 0.029 \\
\hline \multirow[t]{2}{*}{ constant } & 2.801 & -0.763 & $-2.604 * * *$ \\
\hline & 149.047 & 0.712 & 0.739 \\
\hline \multirow{2}{*}{$\begin{array}{l}\text { country effects } \\
\text { sector effects }\end{array}$} & yes & yes & yes \\
\hline & yes & yes & yes \\
\hline Number of obs & 4,347 & 4,347 & 4,346 \\
\hline LR chi2 & 876.11 & 384.50 & 392.36 \\
\hline Prob > chi2 & 0.000 & 0.000 & 0.000 \\
\hline Pseudo R2 & 0.1455 & 0.0642 & 0.1130 \\
\hline Log likelihood & -2573.199 & -2811.513 & -1156.201 \\
\hline
\end{tabular}

Note: In=logarithm; CF/TA=cash-flow on total assets; STDR=short-term debt ratio; LTDR=long-term debt

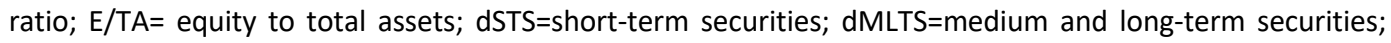
$\mathrm{dOFI=other} \mathrm{financial} \mathrm{instruments;} R \& D /$ sales=R\&D on sales; $A G E=$ age of the company; $S I Z E=$ size of the company; EXPORTER=propensity to export; GROUP=group membership; HSW=high skilled workers; $\mathrm{TFP}=$ total factor productivity; $\mathrm{OWN}=$ ownership concentration.

standard errors in italics* $p<0.10, \quad * * p<0.05, \quad * * * p<0.01$ 
In detail, for those firms that answer to the survey question F1 'What is the overall distribution of your firm's debt structure in percentage terms?', we include a dummy variable for short-term securities (dSTS), a dummy variable for medium and long-term securities (dMLTS), a dummy variable for other financial instruments (dOFI). Each dummy variable equals 1 if the firm used the considered financial instrument, 0 otherwise. The probit estimations for product innovations, process innovations and patenting activity are reported in columns 1, 2 and 3 of Table 6 . The empirical evidence confirms the positive and significant impact of R\&D investments, self-financing and long-term debt on the probability to innovate, even if the effect is relatively more significant for process than product innovations. As in the previous regressions, the short-term debt ratio influences the probability to undertake process innovations, but not the probability of introducing a new product or patent. Analogously, the econometric findings confirm that the ratio of equity over total assets does not exert a significant impact on innovations. The overall evidence for the additional financial instruments (securities and other financial instruments) shows that they are not significant in explaining the probability of innovating. Medium and long-term securities tend to lessen process innovations. Among the other explanatory variables, only the size of the firm and its propensity to export positively and significantly affect at $1 \%$ level - firms' innovative performance. The quota of high skilled workers influences only patents.

\section{Dealing with Endogeneity}

As it has been explained in paragraph 2.2, to limit the endogeneity problem due to reverse causality, we have considered the average of innovation activities over the years 2007-2009 and the set of explanatory variables in 2007 (at the beginning of the period). However, since a potential endogeneity of the regressors can be also due to omitted variables and/or measurement errors, we use Lewbel's approach to handling such problems for binary choice models (see Dong and Lewbel 2012, Lewbel at al. 2012, Lewbel 2004 for details on this methodology).

Lewbel's special regression requires one exogenous continuous variable with a large support that contains zero. Usually, a natural candidate as special regressor is the variable AGE of the firm which is characterized by a relatively high standard deviation and can assume a value of zero. However, in our case the youngest firm is 9 years old, hence this variable does not assume the value zero and cannot be considered a special regressor. For this reason, we choose as special regressor the variable OWN - that is the ownership concentration of companies given by the percentage of ownership held by the main shareholder - which satisfies the requested requisites.

We consider the main predictors CF/TA, STDR, LTDR and E/TA as endogenous, while we consider industry and country dummies as a set of instrumental variables. 
Table 6. Special Regression

\begin{tabular}{|c|c|c|c|}
\hline \multirow[t]{2}{*}{ Variables } & \multirow{2}{*}{$\begin{array}{l}\text { Product innovations } \\
(1)\end{array}$} & \multirow{2}{*}{$\begin{array}{l}\text { Process innovations } \\
(2)\end{array}$} & \multirow{2}{*}{$\begin{array}{l}\text { Patents } \\
(3)\end{array}$} \\
\hline & & & \\
\hline \multirow{2}{*}{$\ln \mathrm{CF} / \mathrm{TA}$} & $0.142 * *$ & $0.321 * * *$ & $0.183^{* *}$ \\
\hline & 0.070 & 0.069 & 0.073 \\
\hline \multirow{2}{*}{ In STDR } & 0.148 & $0.186 * *$ & 0.198 \\
\hline & 0.105 & 0.087 & 0.286 \\
\hline \multirow[t]{2}{*}{ In LTDR } & $0.123^{*}$ & $0.286 * *$ & $0.037 * * *$ \\
\hline & 0.065 & 0.135 & 0.008 \\
\hline \multirow[t]{2}{*}{ In E/TA } & 0.015 & 0.072 & 0.086 \\
\hline & 0.023 & 0.010 & 0.282 \\
\hline \multirow[t]{2}{*}{ R\&D/sales } & $0.268 * * *$ & $0.248 * * *$ & $0.178 * * *$ \\
\hline & 0.054 & 0.068 & 0.030 \\
\hline \multirow[t]{2}{*}{ AGE } & -0.041 & 0.117 & 0.022 \\
\hline & 0.023 & 0.180 & 0.051 \\
\hline \multirow[t]{2}{*}{ In SIZE } & $0.147 * *$ & $0.196 * *$ & $0.201 * *$ \\
\hline & 0.085 & 0.089 & 0.091 \\
\hline \multirow[t]{2}{*}{ EXPORTER } & $0.301 * * *$ & $0.255^{* * *}$ & $0.091 * *$ \\
\hline & 0.068 & 0.065 & 0.042 \\
\hline \multirow[t]{2}{*}{ GROUP } & $-0.036 * *$ & $-0.220 * *$ & $-0.332 * * *$ \\
\hline & 0.018 & 0.101 & 0.059 \\
\hline \multirow[t]{2}{*}{ HSW } & 0.072 & 0.103 & $0.105^{* *}$ \\
\hline & 0.110 & 0.128 & 0.056 \\
\hline \multirow[t]{2}{*}{ TFP } & 0.096 & $0.203^{*}$ & $0.110 * *$ \\
\hline & 0.130 & 0.114 & 0.046 \\
\hline \multirow[t]{2}{*}{ In OWN } & special regressor & special regressor & special regressor \\
\hline & - & - & - \\
\hline \multirow[t]{2}{*}{ constant } & $2.042^{* * *}$ & $2.901 * *$ & 0.539 \\
\hline & 0.563 & 0.486 & 0.143 \\
\hline country dummies & included as IV & included as IV & included as IV \\
\hline sector dummies & included as IV & included as IV & included as IV \\
\hline Number of obs. & 4,130 & 4,130 & 4,129 \\
\hline Wald chi2(10) & 199.76 & 124.65 & 111.11 \\
\hline Prob > chi 2 & 0.000 & 0.000 & 0.000 \\
\hline \multicolumn{4}{|c|}{$\begin{array}{l}\text { Note: In= logarithm; } \mathrm{CF} / \mathrm{TA}=\text { cash-flow on total assets; STDR=short-term debt ratio; } \\
\text { LTDR=long-term debt ratio; } \mathrm{E} / \mathrm{TA}=\text { equity to total assets; R\&D/sales=R\&D on sales; } \mathrm{AGE}=\text { age of } \\
\text { the company; SIZE=size of the company; EXPORTER=propensity to export; GROUP=group } \\
\text { membership; HSW=high skilled workers; TFP=total factor productivity; OWN=ownership } \\
\text { concentration. standard errors in italics; } * p<0.10, * * p<0.05, * * * p<0.01 \text {. Sector and } \\
\text { Country Dummy variables, unreported to save space but available on request, are significant at } \\
1 \% \text { level. }\end{array}$} \\
\hline
\end{tabular}

The special regression reported in Table 6 confirms both the significance and the relative importance of the explanatory variables included in the probit regression. In addition, the variables Group becomes significant with a negative sign, hence being a member of a group does not facilitate knowledge spillovers. 


\section{Conclusions}

Over the last three centuries, many countries have experienced rising prosperity, improvements in living conditions, increases in real income and social welfare. By far the most important determinant of this development has been innovation: new products and novel production processes. Here, we have examined the main determinants of innovative performance for 12,804 manufacturing firms in seven European countries (Austria, France, Germany, Hungary, Italy, Spain and UK) over the period 2007-2009. Three proxies for innovative performance have been considered: product innovations, process innovations and patents. The availability of cash-flow, the accessibility to long-term financing, investments in R\&D activities, the firm size and export propensity have emerged as the main drivers of innovative performance.

A number of policy implications stems from these results. In order to stimulate innovations and, hence, increases in real incomes and economic and social welfare, Governments should implement policies designed to: 1) facilitate the access to long-term debt financing and allow firms to increase the availability of cash-flow; 2) bolster firms to increase investment in research and development activities; 3) stimulate the presence of firms in international markets; 3) favour increases in the size of firms in accordance with the EU anti-trust legislations and fuel methods to support knowledge and collaboration among firms.

Fiscal policies aimed at reducing taxation in R\&D investments and in long-term debt financing could be helpful to this purpose. As far as the availability of cash-flow is concerned, given that cash flow depends mainly on profits in the long-run, it would be useful to reduce taxes on firms and, in particular, taxes on labour. This intervention would allow firms to have more profits, and hence more cash-flow essential for financing innovative investments. Very often some economists, as well as international institutions, have argued that a low tax burden on labour and capital would allow even the less efficient firms to have sufficient profits, weakening their stimulus to innovate. The most relevant example for Italy is represented by the opposition of the European Commission to strong and persistent reduction of taxes on labour employed by manufacturing activities in Southern Italy. Our results show that such cuts would indeed allow firms to increase their free cash-flow, strengthening their innovative performance. This would be also useful to encourage the presence of firms in international markets.

A stimulus to the growth of firm size could be given both by fiscal incentive to the aggregation of firms and by reducing legislation which often penalizes firms when their size increases, in particular as far as labour contracts are concerned. Alternatively, measures to support knowledge (such as technological clusters) and cooperation among firms would help smaller firms to increase innovation activities.

Acknowledgments: The authors would like to thank the Editor of this Journal and an anonymous referee for their helpful comments and suggestions. 


\section{References}

Aghion, P., Bolton, P., 1992. An Incomplete Contracts Approach to Financial Contracting. The Review of Economic Studies 59, 473-494.

Aghion, P., Bond, S., Klemm, A., Marinescu, I., 2004. Technology and Financial Structure: Are Innovative Firms Different? Journal of the European Economic Association 2, 277-288.

Agrawal, K., Maheshwari, Y., 2019. Efficacy of Industry Factors for Corporate Default Prediction. IIMB Management Review 31, 71-77.

Aiello, F., Bonanno, G., Rossi, S.P.S., 2020a. How Firms Finance Innovation. Further Empirics from European SMEs. Metroeconomica 71, 689-714.

Aiello, F., Cardamone, P., Mannarino, L., Pupo, V., 2020b. Does External R\&D Matter for Family Firm Innovation? Evidence from the Italian Manufacturing Industry. Small Business Economics. https:// doi.org/10.1007/s11187-020-00379-z

Algieri, B., Aquino, A., Mannarino, L., 2018. Non-price Competitiveness and Financial Drivers of Exports: Evidences from Italian Regions. Italian Economic Journal 4, 107-133.

Almeida, H., Hsu, P.H., Li, D., 2013. Less is More: Financial Constraints and Innovative Efficiency. Available at SSRN: $\underline{\text { https:/ / ssrn.com/abstract }=1831786}$ or http:/ / dx.doi.org/10.2139/ssrn. $\underline{1831786}$

Altomonte, C., Aquilante, T., Békés, G., Ottaviano, G.I., 2013. Internationalization and Innovation of Firms: Evidence and Policy. Economic Policy 28, 663-700.

Barney, J.B., 1991. Firm Resources and Sustained Competitive Advantage. Journal of Management 17, 99-120.

Bartoloni, E., 2013. Capital Structure and Innovation: Causality and Determinants. Empirica 40, 111-151.

Baumann, J., Kritikos, A., 2016. The Link between R\&D, Innovation and Productivity: Are Micro Firms Different?. Research Policy 45, 1263-1274.

Beck, T., Demirgüç-Kunt, A., Maksimovic, V., 2005. Financial and Legal Constraints to Growth: Does Firm Size Matter?. The Journal of Finance 60, 137-177. 
Bianchini, S., Pellegrino, G., Tamagni, F., 2018. Innovation Complementarities and Firm Growth. Industrial and Corporate Change 27, 657-676.

Brown, J.R., Fazzari, S.M., Petersen, B.C., 2009. Financing Innovation and Growth: Cash Flow, External Equity, and the 1990s R\&D Boom. The Journal of Finance 64, 151-185.

Butzbach, O., Cinquegrana, G., Donati, C., Sarno, D., 2020. Regional Financial Sector and Capital Structure Decisions in a Dualistic Economy. L'industria, Rivista di Economia e Politica Industriale 2, 325-345.

Canepa, A., Stoneman, P., 2005. Financing Constraints in the Inter Firm Diffusion of New Process Technologies. The Journal of Technology Transfer 30, 159-169.

Carpenter, R.E., Petersen, B. C., 2002. Capital Market Imperfections, High-tech Investment, and New Equity Financing. The Economic Journal 112, F54-F72.

Chen, V., Li, J., Shapiro, D.M., Zhang, X., 2014. Ownership Structure and Innovation: An Emerging Market Perspective. Asia Pacific Journal of Management 31, 1-24.

Cosci, S., Meliciani, V., Sabato, V., 2015. Relationship Lending and Innovation: Empirical Evidence on a Sample of European Firms. Economics of Innovation and New Technology 25, 335-357.

Cosh, A., Cumming, D., Hughes, A., 2009. Outside Enterpreneurial Capital. The Economic Journal 119, 1494-1533.

Costanzo, G.D., Succurro, M., 2018. Ownership Structure and Firm Patenting Activity in Italy. Eurasian Economic Review 9, 239-266.

Dong, Y., Lewbel, A., 2012. A Simple Estimator for Binary Choice Models with Endogenous Regressors. Resource Document. Boston College. http: / / fmwww.bc.edu/EC-P/ wp807.pdf. Accessed 30 October 2013.

Fazzari, S.M., Hubbard, R.G., Petersen, B.C., 1988. Financing Constraints and Corporate Investment. Brookings Papers Economic Activity 1, 141205.

Francis, J., Smith, A., 1995. Agency Costs and Innovation: Some Empirical Evidence. Journal of Accounting and Economics 19, 383-409.

Frank, M.Z., Goyal, V.K., 2009. Capital Structure Decisions: Which Factors are Reliably Important?. Financial Management 38, 1-37. 
Giannetti, C., 2012. Relationship Lending and Firm Innovativeness. Journal of Empirical Finance 19, 762-781.

Gill, A., Biger, N., Mathur, N., 2011. The Effect of Capital Structure on Profitability: Evidence from the United States. International Journal of Management 28, 3-15.

Gitman, L.J., Zutter, C.J., 2012. Principles of Managerial Finance. Pearson Prentice Hall, Boston.

Graham, J.R., Harvey, C.R., 2001. The Theory and Practice of Corporate Finance: Evidence from the Field. Journal of Financial Economics 60, 187-243.

Griffith, R., Huergo, E., Mairesse, J., Peters, B., 2006. Innovation and Productivity across Four European Countries. Oxford Review of Economic Policy 22, 483-498.

Griliches, Z., 1995. R\&D and Productivity: Econometric Results and Measurement Issues. In: Stoneman, P. (Ed.), Handbook of the Economics of Innovation and Technological Change. -Blackwell Handbooks in Economics- Blackwell, Oxford, U.K., pp. 52-89.

Guariglia, A., Liu, P., 2014. To What Extent Do Financing Constraints Affect Chinese Firms' Innovation Activities?. International Review of Financial Analysis 36, 223-240.

Hall, B.H., 1992. Investment and Research and Development at the Firm Level: Does the Source of Financing Matter?. NBER Working Paper No. 4096, National Bureau of Economic Research. http: / / www.nber.org/papers/w4096.pdf.

Hall, B.H., 2009. The Financing of Innovative Firms. European Investment Bank Papers 14, 8-28.

Hall, B.H., Lerner, J., 2010. The Financing of R\&D and Innovation. In: Hall, B.H., Rosenberg, N. (Eds.), Handbook of the Economics of Innovation, (Vol.1) Elsevier-North Holland, Amsterdam, The Netherlands pp. 609639.

Hall, B.H., Moncada-Paternò-Castello, P., Montresor, S., Vezzani, A., 2016. Financing Constraints, R\&D Investments and Innovative Performances: New Empirical Evidence at the Firm Level for Europe. Economics of Innovation and New Technology 25, 183-196.

Herrera, A.M., Minetti, R., 2007. Informed Finance and Technological Change: Evidence from Credit Relationships. Journal of Financial Economics 83, 223-269. 
Hosono, K., Tomiyama, M., Miyagawa, T., 2004. Corporate Governance and Research and Development: Evidence from Japan. Economics of Innovation and New Technologies 13, 141-164.

Hottenrott, H., Peters, B., 2012. Innovative Capability and Financing Constraints for Innovation: More Money, More Innovation?. Review of Economics and Statistics 94, 1126-1142.

Hyytinen, A., Toivanen, O., 2005. Do Financial Constraints Hold Back Innovation and Growth? Evidence on the Role of Public Policy. Research Policy 34, 1385-1403.

Hubbard, R.G., 1998. Capital Market Imperfections and Investment. Journal of Economic Literature 36, 193-225.

Huergo, E., Jaumandreu, J., 2004. How Does Probability of Innovation Change with Firm Age?. Small Business Economics 22, 193-207.

Javed, T., Younas, W., Imran, M., 2014. Impact of Capital Structure on Firm Performance. Evidence from Pakistani Firms. International Journal of Academic Research in Economics and Management Science 5, 28-52.

Lewbel, A., 2004. Simple Estimators for Hard Problems: Endogeneity in Discrete Choice Related Models. Resource document. Boston College. https: / / www2.bc.edu/ lewbel/ simple6.pdf.

Lewbel, A., Dong, Y., Yang, T. T., 2012. Comparing Features of Convenient Estimators for Binary Choice Models with Endogenous Regressors. Canadian Journal of Economics 45, 809-829.

Magri, S., 2014. Does Issuing Equity Help R\&D Activity? Evidence from Unlisted Italian High-tech Manufacturing Firms. Economics of Innovation and New Technology 23, 825-854.

Magri, S., 2009. The Financing of Small Innovative Firms: the Italian Case. Economics of Innovation and New Technology 18, 181-204.

Mina, A., Lahr, H., Hughes, A., 2013. The Demand and Supply of External Finance for Innovative Firms. Industrial and Corporate Change 22, 869901.

Minetti, R., Murro, P., Paiella, M., 2015. Ownership Structure, Governance, and Innovation. European Economic Review 80, 165-193.

Mohnen, P., Roller, L.H., 2005. Complementarities in Innovation Policy. European Economic Review 49, 1431-1450.

Mohnen, P., Palm, F., Loeff, S., Tiwari, A., 2008. Financial Constraints and Other Obstacles: Are They a Threat to Innovation Activity?. De Economist 156, 201-214. 
Musso, P., Schiavo, S., 2008. The Impact of Financial Constraints on Firm Survival and Growth. Journal of Evolutionary Economics 18, 135-149.

Myers, S., Majluf, N.S., 1984. Corporate Financing and Investment Decisions when Firms Have Information that Investors Do Not Have. Journal of Financial Economics 13: 187-221.

Parpaleix, L., Levillain, K., Segrestin, B., 2019. Financing the Next Generations of Innovation: New Dimensions in the Private Equity Model. Journal of Innovation Economics \& Management 29, 7-41.

Pavitt, K., 1985. Patent Statistics as Indicators of Innovative Activities: Possibilities and Problems. Scientometrics 7, 77-99.

Purwohandoko, P., 2017. The Influence of Firm's Size, Growth, and Profitability on Firm Value with Capital Structure as the Mediator: A Study on the Agricultural Firms Listed in the Indonesian Stock Exchange. International Journal of Economics and Finance 9, 103-110.

Savignac, F., 2009. Impact of Financial Constraints on Innovation: What Can Be Learned from a Direct Measure?. Economics of Innovation and New Technology 17, 553-569.

Shapiro, D., Tang, Y., Wang, M., Zhang, W., 2015. The Effects of Corporate Governance and Ownership on the Innovation Performance of Chinese SMEs. Journal of Chinese Economic and Business Studies 13, 311-335.

Singh, N.P., Bagga, M., 2019. The Effect of Capital Structure on Profitability: An Empirical Panel Data Study. Jindal Journal of Business Research 8, 65-77.

Schmookler, J., 1954. The Level of Inventive Activity. The Review of Economics and Statistics 36, 183-190.

Stulz, R., 1990. Managerial Discretion and Optimal Financing Policies. Journal of Financial Economics 26, 3-27.

Wang, T., Thornhill, S., 2010. R\&D Investment and Financing Choices: A Comprehensive Perspective. Research Policy 39, 1148-1159.

Williamson, O., 1988. Corporate Finance and Corporate Governance. The Journal of Finance 43, 567-591.

Wruck, K.H., 1990. Financial Distress, Reorganization, and Organizational Efficiency. Journal of Financial Economics 27, 419-444.

Yafeh, Y., Yosha, O., 2003. Large Shareholders and Banks: Who Monitors and How?. The Economic Journal 113, 128-146. 


\section{Appendix}

Table A.1. Correlation Matrix

\begin{tabular}{|c|c|c|c|c|c|c|c|c|c|c|c|}
\hline & $R \& D$ & $\mathrm{CF} / \mathrm{TA}$ & STDR & LTDR & $\mathrm{E} / \mathrm{TA}$ & AGE & SIZE & EXPORTER & GROUP & HSW & TFP \\
\hline$R \& D$ & 1.00 & & & & & & & & & & \\
\hline \multirow[t]{2}{*}{$\mathrm{CF} / \mathrm{TA}$} & 0.0084 & 1.00 & & & & & & & & & \\
\hline & 0.4110 & & & & & & & & & & \\
\hline \multirow[t]{2}{*}{ STDR } & 0.0059 & -0.0025 & 1.00 & & & & & & & & \\
\hline & 0.5078 & 0.8054 & & & & & & & & & \\
\hline \multirow[t]{2}{*}{ LTDR } & -0.011 & -0.0003 & 0.0652 & 1.00 & & & & & & & \\
\hline & 0.2146 & 0.9729 & 0.0000 & & & & & & & & \\
\hline \multirow[t]{2}{*}{$\mathrm{E} / \mathrm{TA}$} & 0.0113 & 0.0158 & -0.3790 & -0.8656 & 1.00 & & & & & & \\
\hline & 0.2074 & 0.1229 & 0.0000 & 0.0000 & & & & & & & \\
\hline \multirow[t]{2}{*}{ AGE } & 0.0569 & -0.0027 & 0.0303 & -0.0069 & 0.0023 & 1.00 & & & & & \\
\hline & 0.0000 & 0.7929 & 0.0007 & 0.4383 & 0.8014 & & & & & & \\
\hline \multirow[t]{2}{*}{ SIZE } & 0.0374 & -0.0012 & -0.0010 & -0.0009 & 0.0018 & 0.0622 & 1.00 & & & & \\
\hline & 0.0000 & 0.9093 & 0.9075 & 0.9165 & 0.8409 & 0.0000 & & & & & \\
\hline \multirow[t]{2}{*}{ EXPORTER } & 0.2463 & 0.0068 & 0.0047 & -0.0128 & 0.0146 & 0.0945 & 0.0463 & 1.00 & & & \\
\hline & 0.0000 & 0.5049 & 0.5983 & 0.1511 & 0.1016 & 0.0000 & 0.0000 & & & & \\
\hline \multirow[t]{2}{*}{ GROUP } & 0.0775 & -0.0060 & -0.0053 & -0.0048 & 0.0068 & 0.0507 & 0.1201 & 0.1318 & 1.00 & & \\
\hline & 0.0000 & 0.5571 & 0.5510 & 0.5917 & 0.4498 & 0.0000 & 0.0000 & 0.0000 & & & \\
\hline \multirow[t]{2}{*}{ HSW } & 0.0019 & 0.0145 & 0.0063 & 0.0076 & -0.0088 & 0.0309 & 0.0261 & -0.0556 & 0.0509 & 1.00 & \\
\hline & 0.8495 & 0.2033 & 0.5308 & 0.4517 & 0.3876 & 0.0020 & 0.0092 & 0.0000 & 0.0000 & & \\
\hline \multirow[t]{2}{*}{ TFP } & -0.032 & 0.0857 & 0.0865 & 0.0556 & 0.0834 & -0.0008 & -0.0260 & -0.0978 & -0.0420 & 0.0512 & 1.00 \\
\hline & 0.0053 & 0.0000 & 0.0000 & 0.0000 & 0.0000 & 0.9460 & 0.0274 & 0.0000 & 0.0004 & 0.0001 & \\
\hline
\end{tabular}

Note: $\mathrm{R} \& \mathrm{D}=$ research and development investments/total sales; $\mathrm{CF} / \mathrm{TA}=$ cash-flow on total assets; STDR=short-term debt ratio; LTDR=long-term debt ratio; $E / T A=$ equity to total assets; $A G E=$ age of the company; SIZE=size of the company; EXPORTER=propensity to export; GROUP=group membership; HSW=high skilled workers; TFP=total factor productivity; $\mathrm{OWN=ownership}$ concentration.

p-values in Italics. 